\title{
Analisis Perubahan Lahan Sawah Areal Pengairan Bendungan Dikaitkan Dengan Ketahanan Pangan
}

\author{
Nur Sah Jidah ${ }^{1)}$, La Ode Muh. Golok Jaya ${ }^{2}$, Laode Muh. Iradat Salihin ${ }^{3)}$ \\ ${ }^{12233)}$ Program Studi Geografi Fakultas Ilmu dan Teknologi Kebumian UHO
}

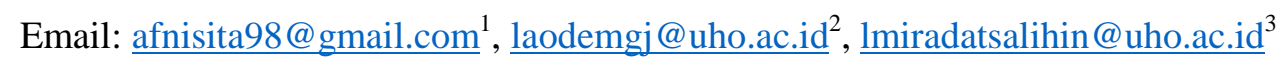

\begin{abstract}
Abstrak: Konversi lahan pertanian menimbulkan dampak negatif terhadap pembangunan pertanian, sehingga menurunkan kapasitas produksi pertanian, rusaknya sistem pengairan dan hilangnya investasi yang telah ditanamkan dalam membangun jaringan irigasi dan pembuatan teras pematang sawah. Penelitian ini bertujuan untuk: (1) mengetahui perubahan lahan sawah menggunakan Citra Landsat multitemporal; (2) mengetahui pengaruh perubahan lahan sawah areal Bendungan Wawotobi terhadap pemenuhan kebutuhan dan ketahanan pangan. Metode analisis data dalam penelitian ini adalah: (1) analisis penggunaan lahan dengan metode berbasis objek; (2) analisis estimasi produksi dan kebutuhan beras. Hasil penelitian ini antara lain: (1) perubahan luas lahan sawah tahun 2009 seluas 4.291,6 ha dan meningkat menjadi seluas 7.162,67 ha pada tahun 2018; (2) analisis estimasi produksi tanaman padi pada empat Kecamatan di Kabupaten Konawe dalam areal Pengairan Bendungan Wawotobi, yaitu Kecamatan Pondidaha didapat sebesar 8.138,99 ton dan kebutuhan beras 837,9 ton/tahun dengan jumlah penduduk 11.970 jiwa, Kecamatan Wonggeduku sebesar 48.416,13 ton dan kebutuhan beras 952,14 ton/tahun dengan jumlah penduduk 13.602 jiwa, Kecamatan Wawotobi sebesar 9.801,20 ton dan kebutuhan beras 1.619,8 ton/tahun dengan jumlah penduduk 23.140 jiwa, dan Kecamatan Unaaha sebesar $1.984,27$ ton dan kebutuhan beras $1.821,89$ ton/tahun dengan jumlah penduduk 26.027 jiwa.
\end{abstract}

\section{Kata Kunci: Sawah, Perubahan Lahan Sawah, Ketahanan Pangan}

Abstract: Conversion of agriculture land has a negative impact on agricultural development, thereby reducing agricultural production capacity, undermining irrigation system and loss of investment in agricultural sector. This research aims to: (1) know the change of land rice fields use Landsat multitemporal imageries; (2) know the influence of rice fied change in area of Wawotobi Dam to fulfill food needs and security. Data analysis methods in this study are: (1) object-based methods to land use analysis; (2) analysis of estimated production and rice requirements. The results of this study are: (1) changes in the area of paddy fields in 2009 covering 4,291.6 acre and increasing to 7,162.67 acre in 2018; (2) analysis of estimated rice production in four sub-districts in Konawe District within the Wawotobi Dam Irrigation Area, i.e. Pondidaha Sub-District obtained 8,138.99 tons and the need for rice 837.9 tons /year with a population of 11,970 persons, Wonggeduku Sub-District 48,416.13 tons and the need for rice 952.14 tons /year with a population of 13,602 persons, Wawotobi Sub-District of 9,801.20 tons and the need for rice 1,619.8 tons /year with a population of 23,140 persons, and Unaaha Sub-District of $1,984.27$ tons and the need for rice 1,821.89 tons /year with a population of 26,027 persons.

Keywords: paddy field, rice field change, food security 


\section{PENDAHUUAN}

Lahan Sawah adalah suatu tipe penggunaan lahan, yang untuk pengolahannya memerlukan genangan air. Sawah selalu mempunyai permukaan yang datar atau didatarkan (dibuat teras), dan dibatasi oleh pematang untuk menahan air genangan (Syaf et al., 2017).

Pada tingkatan mikro, proses alih fungsi lahan pertanian (konversi lahan) dapat dilakukan oleh petani sendiri atau dilakukan oleh pihak lain. Alih fungsi lahan yang dilakukan oleh pihak lain memiliki dampak yang lebih besar terhadap penurunan kapasitas produksi pangan karena proses alih fungsi lahan tersebut biasanya mencakup hamparan lahan yang cukup luas, terutama ditujukan untuk pembangunan kawasan perumahan. Proses alih fungsi lahan yang dilakukan oleh pihak lain tersebut. Potensi lahan di suatu kawasan yang produktivitasnya kurang bagus akan menghasilkan tingkat pendapatan (revenue) yang relatif rendah, sehingga berdampak pada rendahnya pendapatan perkapita (income) kawasan tersebut. Dalam hal ini produktivitas lahan merupakan nilai koefisien suatu luasan panen dari pola tanam tertentu yang berhasil dikerjakan secara riil baik mendapatkan hasil dari panen saja (Irawan, 2016).

Kabupaten Konawe dikenal sebagai daerah yang berperan penting dalam produksi pertanian di Provinsi Sulawesi Tenggara khusunya padi dan palawija. Kabupaten Konawe mempunyai beberapa sungai besar yang cukup potensial untuk pengembangan pertanian, irigasi dan pembangkit tenaga listrik salah satunya seperti Sungai Konaweeha. Sungai Konaweeha mempunyai debit air \pm 200 $\mathrm{m}^{3} /$ detik. Dari sana telah dibangun bendungan air Wawotobi yang mampu mengairi sawah seluas $\pm 18.000 \mathrm{Ha}$.

Daerah Irigasi dan Bendung Wawotobi di Kabupaten Konawe Sulawesi Tenggara dibangun pada tahun $1981 \mathrm{~s} / \mathrm{d}$ 1987 dan merupakan salah satu irigasi teknis yang terbesar yang ada di Sulawesi 64 --- April
Tenggara sampai saat ini, Di Wawotobi mengambil sumber air dari Bendung Wawotobi di Kabupaten Konawe Provinsi Sulawesi Tenggara. Wawotobi berdasarkan perencanaan awal diharapkan mampu mengairi lahan dengan potensi $18.000 \mathrm{Ha}$. Namun selama kurang waktu lebih 27 tahun perkembangan luas potensial eksisting baru mencapai 16.572,26 Ha serta luas fungsional eksisting 9.872,54 Ha, sehingga antara luas potensial eksisting dengan luas pontensi awal desain masih memiliki perbedaan $1.427,74 \mathrm{Ha}$.

Perhitungan estimasi produksi padi kali ini lebih menekankan pada luas lahan pertanian padi dan kesesuaian lahan padi yang terdapat di Kabupaten Brekabupaten Konawe. Kesesuaian lahan padi digunakan untuk mengetahui produktivitas dan masa panen lahan pertanian sawah di Kabupaten Konawe sehingga dapat meningkatkan tingkat hasil estimasi produksi pertanian padi. Setiap lahan pertanian padi pasti memiliki produktivitas yang berbeda sesuai dengan kelas kesesuaian lahan dan pola tanam padi dalam satu tahun. Pemanfaatan data penginderaan jauh dan sistem informasi geografi diharapkan mampu menjadi salah satu alternatif dalam perhitung produksi padi yang lebih efektif dan efisien. Seperti yang pernah dilakukan oleh (Ashidqi and Taryono, 2017).

Adapun Tujuan penelitian ini adalah 1) Untuk mengetahui perubahan lahan sawah dari Citra Landsat multitemporal. 2) Untuk mengetahui pengaruh perubahan lahan sawah areal Bendungan Wawotobi terhadap pemenuhan kebutuhan dan Ketahanan Pangan masyarakat Kabupaten Konawe.

\section{METODOLOGI PENELITIAN}

Penelitian ini dilakukan di Daerah Irigasi (DI) Wawotobi, Kabupaten Konawe, Provinsi Sulawesi Tenggara. Secara geografis Kabupaten Konawe terletak dibagian Selatan Khatulistiwa, melintang dari Utara Ke Selatan antara $02^{\circ}$ $45^{\prime}$ dan $04^{\circ} 15^{\prime}$ Lintang selatan, membujur 
ISSN : 2549-9181| e-ISSN : 2684-6705

| Vol.5 | No.1 | 2021

dari ke Barat ke Timur antara $121^{\circ} 15^{\prime}$ dan $123^{\circ} 30^{\prime}$ Bujur Timur.

Adapun batas-batas administratif Kabupaten Konawe:

1. Utara : Berbatasan dengan Propinsi Sulawesi Tengah
2. Timur : Berbatasan dengan Kota Kendari

3. Selatan : Berbatasan dengan Kabupaten Konawe Selatan

4. Barat : Berbatasan dengan Kabupaten Kolaka.

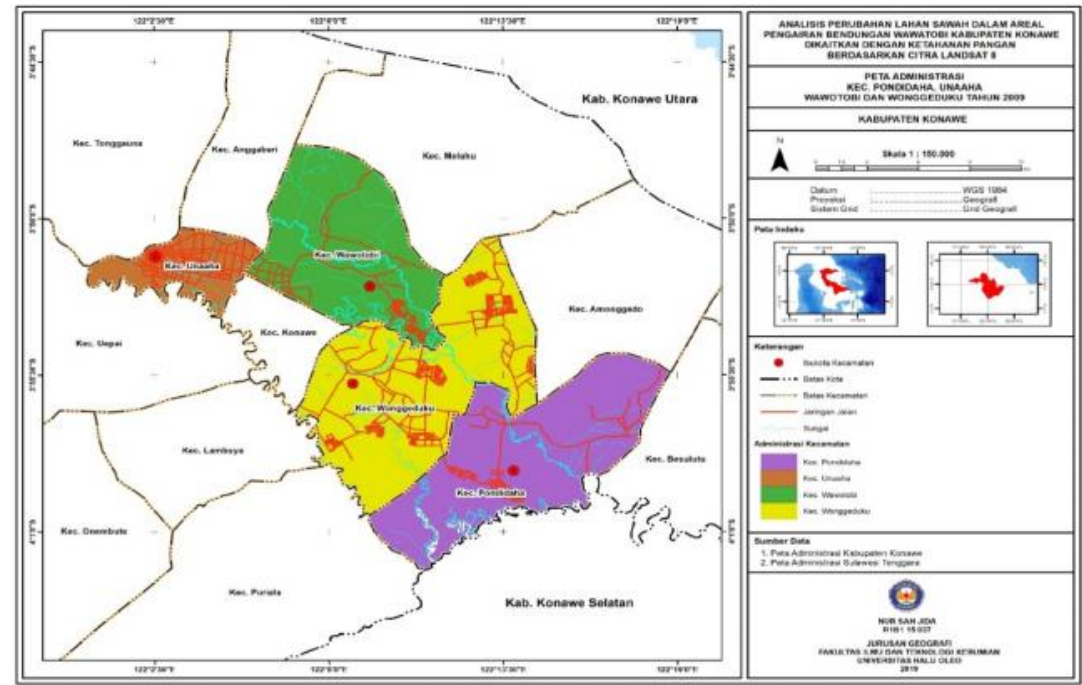

Gambar 1. Peta Lokasi Penelitian

\section{a. Tahap Pengolahan Data}

Sebelum melakukan analisis data untuk menjawab masalah dan tujuan penelitian, terlebih dahulu data disiapkan melalui tahapan pengolahan data.

\section{Koreksi Radiometrik}

Koreksi radiometrik ditujukan untuk memperbaiki nilai piksel supaya sesuai dengan yang seharusnya yang biasanya mempertimbangkan faktor gangguan atmosfer sebagai sumber kesalahan utama. Persamaan yang digunakan untuk Koreksi Radiometrik sebagai berikut:

1. Koreksi Citra Landsat 5TM dan Landsat 7ETM+

a) Konversi digital number ke radian

$\mathrm{L} \lambda=\frac{(\mathrm{LMAX} \lambda-\mathrm{LMIN} \lambda)}{\mathrm{Q} \text { cal } \max x-\mathrm{Q} \text { cal } \min } \mathrm{X}(\mathrm{Q}$ calmax $-\mathrm{Qcalmin})+\mathrm{Lmir}$

(1)

$\mathrm{L} \lambda$ adalah Spektral Radian di aperture sensor(W/(m2sr $\mu \mathrm{m}), \quad \operatorname{LMIN} \lambda$ adalah Spektral pada sensor radian pada skala
Qcalmin $\mathrm{W} /(\mathrm{m} 2 \mathrm{sr} \mu \mathrm{m})$, LMAX $\lambda$ adalah Spektral pada sensor radian pada skala Qcalmax W/(m2 sr $\mu \mathrm{m})$ dan $\mathrm{DN}=$ Digital Number.

b) Konversi radian ke ToA Reflectance

$\mathrm{pP}=\frac{\mathrm{Ix} \mathrm{x} \mathrm{L}_{\lambda \times \mathrm{d}^{0}}}{\mathrm{ESUN} \times \mathbf{x} \operatorname{Cos} \theta_{\mathrm{S}}}$

$\rho \mathrm{P}$ adalah TOA Reflectance, II adalah Konstanta matematika; 3.14159, L $\lambda$ adalah Spektral Radian di aperture sensor(W/(m2sr $\mu \mathrm{m})$, D adalah jarak bumimatahari dalam satuan astronomi, ESUN $\lambda$ adalah Rata-rata exoatmospheric solar irradiance $\mathrm{W} /(\mathrm{m} 2 \mu \mathrm{m})$ dan $\Theta_{\mathrm{s}}$ Sudut zenit matahari (derajat)

\section{Koreksi Citra Landsat 8 OLI}

a) Konversi nilai DN ke ToA Reflectance

$p \lambda^{\prime}=\mathrm{Mp} \mathrm{Qcal}+\mathrm{Ap}$

$\rho \lambda$ ' adalah TOA reflektansi, tanpa koreksi untuk sudut matahari, $\mathrm{Mp}$ adalah 
Reflectance_Mult_Band_x , dimana x adalah nomor band, Qcal adalah Reflectance_Add_Band_x , dimana $\mathrm{x}$ adalah nomor band dan Ap adalah Nilai digital number ( $\mathrm{DN}$ ).

b) Koreksi ToA Reflektan dengan sudut matahari

$\rho \lambda=\frac{\rho \lambda^{\prime}}{\operatorname{Cos}(\theta S Z)} \operatorname{Atau} \frac{\rho \lambda^{\prime}}{\operatorname{Sin}(\theta S E)}$.

$\rho \lambda$ adalah Reflektan TOA terkoreksi sudut matahari, OSZadalah Sudut elevasi matahari, $\Theta S E$ adalah Sudut zenith matahari $\theta \mathrm{SZ}=90^{\circ}-\theta \mathrm{SE}$.

\section{Koreksi Geometrik}

Pada penelitian ini proses koreksi geometrik dilakukan pada Citra Landsat 5 dengan waktu perekaman tahun 1996 resolusi $30 \mathrm{~m}$, Citra Landsat 5 dengan waktu perekaman tahun 2006, dan Citra landsat 8 dengan waktu perekaman 2018. Koreksi geometri melalui pembuatan ground control point (GCP) yang dilakukan dengan mencocokkan koordinat Citra Landsat 5 dan Citra dengan Citra Landsat 8 yang koordinat geografisnya telah terkoreksi.

Orde yang digunakan dalam koreksi geometric yaitu orde 2 , karena kondisi topografi lokasi penelitian ini yaitu landai berbukit dengan menggunakan 30 titik control tanah dan memiliki nilai RMS untuk Citra L5 tahun 2009 sebesar 0.00003 .

\section{Cropping Citra}

Pemotongan citra dilakukan untuk membatasi daerah penelitian sehingga memudahkan analisis pada komputer. Pemotongan citra ini memfokuskan saja untuk lokasi penelitian yaitu wilayah Kecamatan Unaaha, Kecamatan Wawotobi, Kecamatan Wonggeduku, Kecamatan Pondidaha.

\subsection{Teknik analisis Data}

\section{a) Analisis Penggunaan Lahan Klasifikasi Citra}

Metode klasifikasi berbasis objek merupakan metode klasifikasi dengan konsep segmentasi dan analisis citra berdasarkan karakteristik spasial, spectral dan skala temporal sehingga menghasilkan kelas-kelas tertentu. Metode klasifikasi berbasis objek melibatkan satu piksel yang dikelompokan ke dalam objek berdasarkan kesamaan spektral atau variabel seperti ladang, unit geologi dan lainnya.

\section{Uji Akurasi}

Uji akurasi bertujuan untuk mengetahui tingkat kebenaran dari model klasifikasi yang telah dilakukan dengan data validasi lapangan (ground check). Penggunaan citra satelit resolusi tinggi di gunakan sebagai acuan dalam interpretasi objek yang memiliki daerah sangat sulit di jangkau jika di lakukan survei lapangan (Utami et al., 2016).

\section{b) Analisis perubahan luas lahan sawah}

Untuk mengetahui perubahan luas mangrove diperlukan formula sebagai berikut :

$$
\Delta \mathrm{L}=\frac{\mathrm{Lt} 2-\mathrm{L} \mathrm{t} \mid}{\Delta \mathrm{t}}
$$

$\Delta \mathrm{L} \quad=$ Laju Perubahan Luas

Lt2 = Luas Tahun berikutnya (ha)

Lt1 = Luas Tahun sebelumnya (ha)

$\Delta \mathrm{t}=$ Selisih waktu awal tahun dan akhir tahun.

\section{c) Estimasi produksi lahan pertanian padi}

Penelitian ini menggunakan analisis dengan memanfaatkan data luas lahan pertanian yang diperoleh dari pengolahan data citra Landsat 8 yang telah melalui tahapan survei lapangan, serta data produksi padi yang diperoleh dari data BPS kabupaten konawe sehingga diperoleh nilai produktivitas lahan pertanian padi.

Rata-rata

Produktivitas $=\frac{\text { Total Produktivitas }}{\text { Banyaknya Produktivitas }}$ 
Estimasi Tanaman Padi $=$ Luas Lahan

Pertanian x Nilai Rata-rata

\section{d) Estimasi Kebutuhan Beras}

Penelitian ini menghitung estimasi kebutuhan beras penduduk menggunakan data jumlah penduduk Kecamatan Tahun 2018 dan rata-rata konsumsi padi per kapita seminggu Kabupaten Konawe. Berdasarkan data jumlah penduduk di atas maka dapat diketahui prediksi kebutuhan beras di empat Kecamatan tahun 2018.

Kebutuhan beras total $=$ Jumlah penduduk $\mathrm{x}$ konsumsi beras

\section{Hasil dan Pembahasan}

Dalam penelitian (Syaf et al., 2017) menyatakan bahwa Lahan Sawah adalah suatu tipe penggunaan lahan, yang untuk pengolahannya memerlukan genangan air. Sawah selalu mempunyai permukaan yang datar atau didatarkan (dibuat teras), dan dibatasi oleh pematang untuk menahan air genangan.

Pemenuhan kebutuhan pangan sangat penting dalam hal ini produksi beras dan kebutuhan beras terutama di Kabupaten Konawe. Dalam penelitian ini menganalisis empat Kecamatan yaitu Kecamatan Unaaha, Kecamatan Wawotobi, Kecamatan Wonggeduku, dan Kecamatan Pondidaha seperti dalam penelitian (Febriyanto et al., 2012) menyatakan bahwa pangan adalah kebutuhan dasar manusia sehingga pemenuhannya bukan hanya untuk memenuhi hak asasi setiap rakyat Indonesia atau hanya sebagai kewajiban moral saja, tetapi juga merupakan investasi ekonomi maupun sosial dalam rangka pembentukan generasi yang lebih baik pada masa yang akan datang. Indonesia mempunyai keanekaragaman hayati, ekosistem, dan budaya yang sangat tinggi. Kemampuan dan keberadaan biodiversitas pertanian lokal harus dimanfaatkan dan dikembangkan guna meningkatkan dan mempertahankan ketahanan pangan lokal, daerah dan nasional

Daerah Irigasi Wawotobi memanfaatkan air dari Sungai Konaweeha, dengan pengambilan air maksimal 26 $\mathrm{M}^{3} / \mathrm{dt}$ untuk mengairi sawah seluas 18.000 ha. Pengambilan air dari sungai di lakukan pada 2 (dua) intake. Pengambilan air pada intake kanan sebesar $2.16 \mathrm{~m} / \mathrm{s}$ untuk mengairi luas areal $1.500 \mathrm{Ha}$ dan intake kiri $20.10 \mathrm{~m} / \mathrm{s}$ untuk mengairi luas areal 16.500 Ha. Namun sampai dengan saat ini luas areal yang diairi hanya 9.447,80 $\mathrm{Ha}$, yaitu kanan $747 \mathrm{Ha}$, dan kiri 8.700,80 dalam penelitian (Syaifuddin et al., 2013).

\subsection{Penggunaan Lahan}

Kelas Penggunaan lahan dalam penelitian ini di klasifikasikan sebanyak 9 Kelas, di antaranya yaitu:

Tabel 1. Kelas Pemggunaan Lahan yang digunakan.

\begin{tabular}{clc}
\hline No & Kelas Penggunaan Lahan & Kode \\
\hline 1 & Hutan Primer & HP \\
\hline 2 & Hutan Sekunder & HS \\
\hline 3 & Perkebunan & $\mathrm{Pk}$ \\
\hline 4 & Permukiman & $\mathrm{Pr}$ \\
\hline 5 & Semak Belukar & $\mathrm{SB}$ \\
\hline 6 & Sawah & $\mathrm{S}$ \\
\hline 7 & Hutan Bakau & $\mathrm{HB}$ \\
\hline 8 & Tubuh Air & $\mathrm{TA}$ \\
\hline 9 & Lahan Terbuka & $\mathrm{Lt}$ \\
\hline
\end{tabular}

(Sumber: Hasil Analisis Penggunan Lahan)

a. Penggunaan Lahan Tahun 2009-2018

Untuk perubahan luas penggunaan lahan dapat dilihat pada grafik berikut, untuk tahun 2009 (Biru), dan 2018 (Orange), perubahannya dapat dilihat pada grafik 2.

Untuk peta penggunaan lahan wilayah Kabupaten Konawe yaitu mencakup Kecamatan Unaaha, Kecamatan Wawotobi, Kecamatan Wonggeduku dan Kecamatan Pondidaha dapat dilihat pada gambar 3 . 
Luas PL Tahun 2009

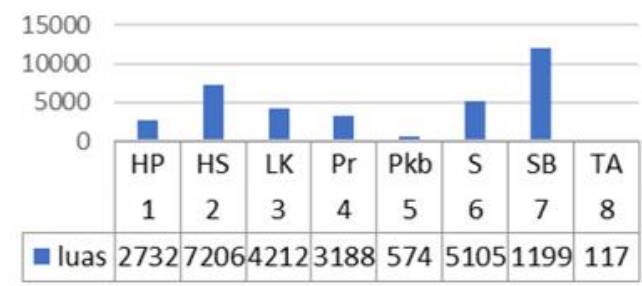

(a)

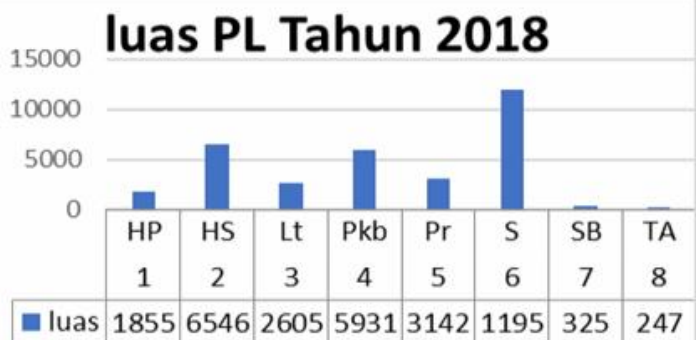

(b)

Gambar 2. Grafik Luas Penggunaan Lahan

Tahun (a) 2009 dan (b) 2018.

Penggunaan lahan dibagi menjadi 12 kelas yaitu tidak terklasifikasi (awan), hutan primer (hijau tua), hutan sekunder (hijau muda), lahan kosong (pink), permukiman (kuning), perkebunan (ungu), semak belukar (coklat), sawah (putih), tubuh air (biru). Untuk perbandingannya dari tahun 2009 (a) dan 2018 (b) dapat dilihat pada gambar berikut:

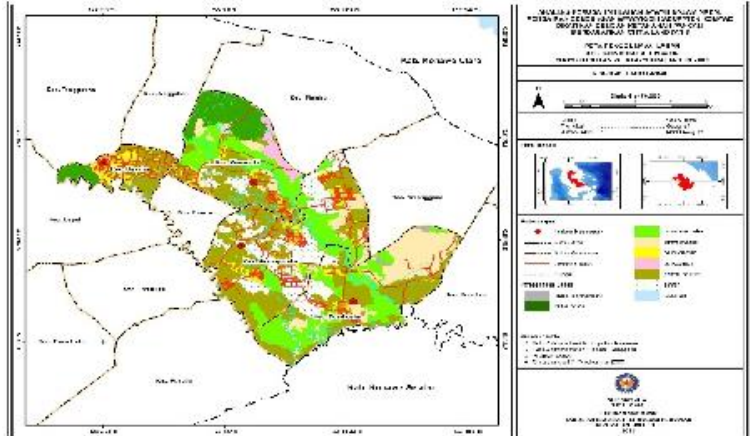

(a)

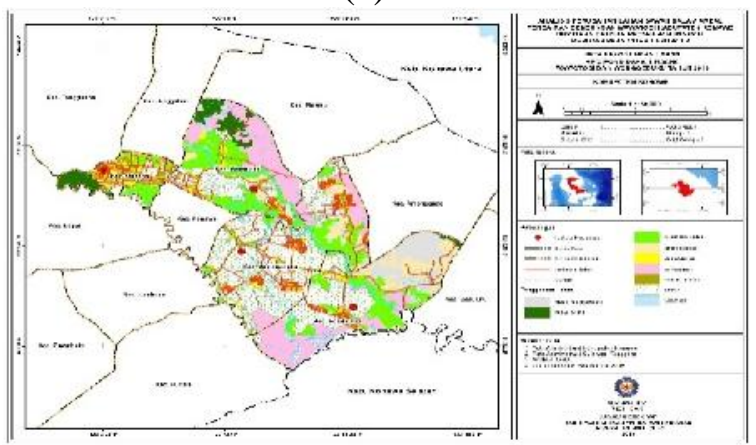

(b)

Gambar 3. Peta Penggunaan Lahan Tahun (a) 2009 dan (b) 2018.

Penggunaan lahan di atas bertujuan untuk mengetahui bagaimana perubahan lahan sawah yaitu dari sawah menjadi bukan sawah dan bukan sawah menjadi sawah yang terjadi pada dua tahun berbeda diantaranya 2009 dan 2018. Perubahan lahan sawah dapat dilihat pada gambar 4 .

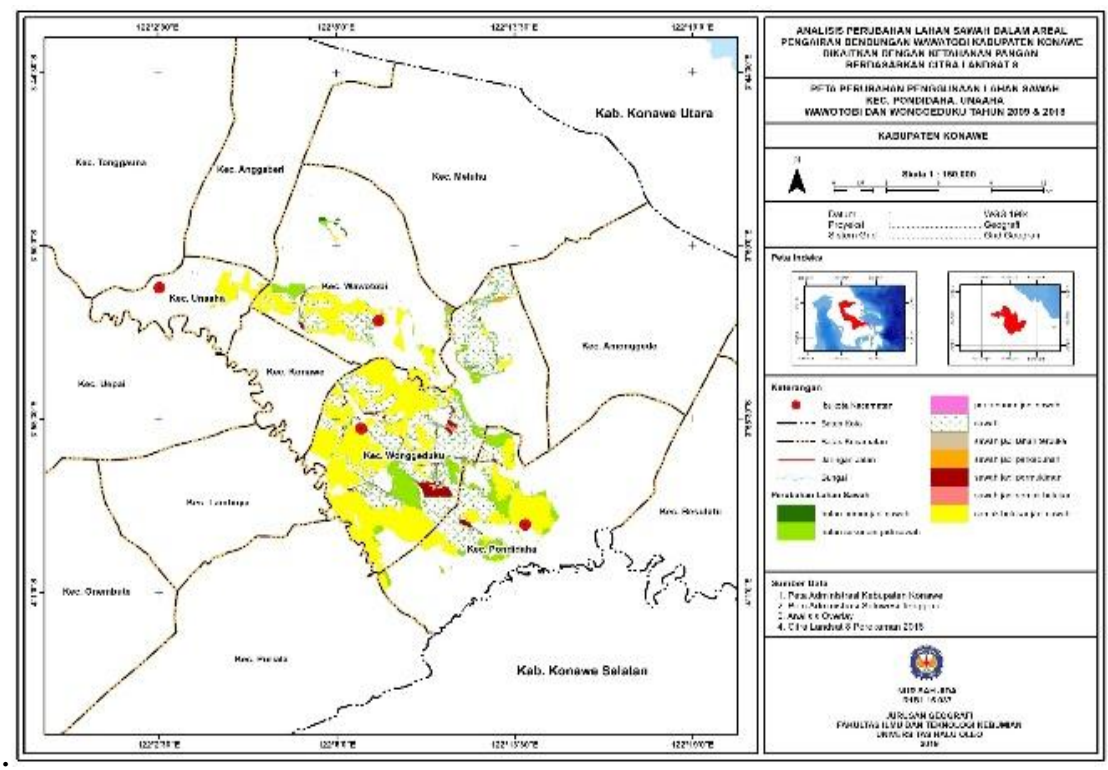

Gambar 4. Peta Perubahan Lahan Sawah 


\subsection{Perubahan Luas Lahan Sawah}

Penelitian menggunakan analisis perubahan lahan sawah pada empat kecamatan di Kabupaten Konawe dari hasil analisis terdapat perubahan yang sangat menonjol yaitu perubahan pada luas sawah pada Kecamatan Pondidaha luas lahan sawah berkurang ini disebabkan oleh alih fungsi laan menjadi tanaman jagung. Pada Kecamatan Wonggeduku luas lahan sawah sangat meningkat dari tiga Kecamatan ini disebabkan bertambahnya jumlah penduduk, dua Kecamatan tersebut mengalami peningkatan/penurunan (Gambar 5). Seperti dalam penelitian Irawan, 2001 menyatakan Perubahan lahan sawah adalah bertambah atau berkurangnya luasan sawah pada suatu periode.

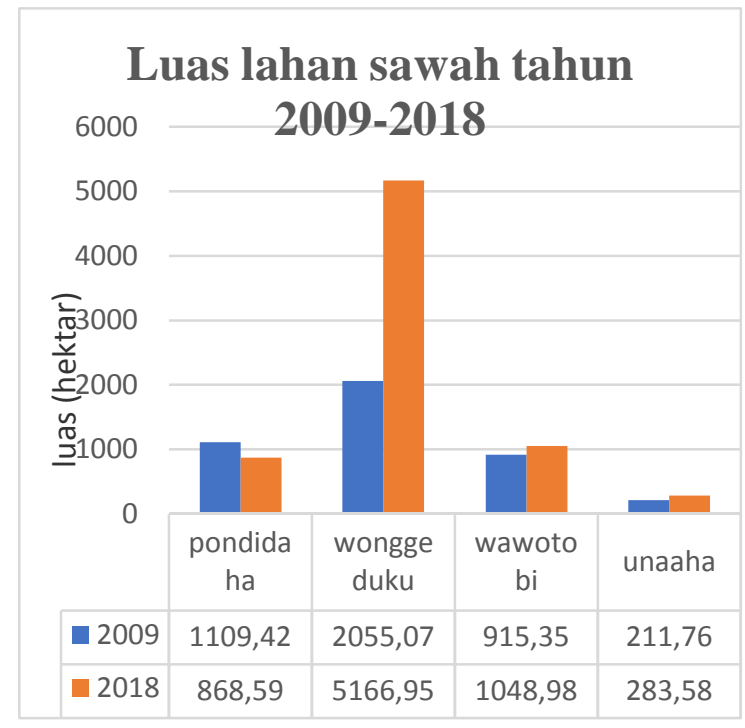

Gambar 5. Grafik Perubahan luasan lahan sawah tahun 2009 dan 2018.
Perubahan lahan sawah terjadi apabila peningkatan luasan lahan sawah terjadi akibat adanya pertumbuhan penduduk yang tinggi secara bersamaan meningkatnya kebutuhan lahan ataupun pengurangan luasan sawah terjadi apabila suatu daerah terdapat sawah kemudian sawah gagal panen akibat hama atau kurangnya modal untuk penggarapan lahan dan konversi lahan atau alih fungsi lahan. Untuk luas lahan sawah yang mengalami perubahan sangat luas yaitu pada Kecamatan Wonggeduku dari tahun 20092018 untuk maing-masing dapat dilihat pada gambar 5 .

\subsection{Estimasi Produksi Tanaman Padi}

Analisis ini di gunakan untuk mengetahui estimasi produksi tanaman padi pada tiap Kecamatan yaitu Kecamatan Pondidaha, Wonggeduku, Wawotobi, dan Unaaha pada tahun 2018. Berdasarkan hasil estimasi per Kecamatan. Pada Kecamatan Wonggeduku dari empat Kecamatan dalam areal Bendungan Irigasi Wawotobi memiliki produksi terbanyak mencapai 48.416,13 Ton total produksi padi di Kabupaten Konawe dan produksi terendah yaitu pada Kecamatan Unaaha dari hasil estimasi produksi beras didapat $1.984,27$ Ton. Berikut ini tabel hasil produksi lahan pertanian padi di Kabupaten Konawe setiap Kecamatan berdasarkan kelas produktivitas lahan. Estimasi produksi tanaman padi dapat dilihat pada tabel 2 sebagai berikut

Tabel 2 . Estimasi Produksi Padi Tahun 2018

\begin{tabular}{|c|c|c|c|c|c|c|}
\hline No & Kecamatan & Kelas Produktivitas & $\begin{array}{c}\text { Jumlah Produksi } \\
\text { Padi }\end{array}$ & Luas Lahan & Produktivitas & $\begin{array}{c}\text { Estimasi } \\
\text { Produksi Padi }\end{array}$ \\
\hline 1 & Pondidaha & $\begin{array}{c}\text { Lahan panen sesui } 2 \\
\text { kali panen }\end{array}$ & 9,21 & 868.59 & 10,61 & $8.138,99$ \\
\hline 2 & Wonggeduku & $\begin{array}{c}\text { Lahan panen sesui } 2 \\
\text { kali panen }\end{array}$ & 15,76 & $5.166,95$ & 3,05 & $48.416,13$ \\
\hline 3 & Wawotobi & $\begin{array}{c}\text { Lahan panen sesui } 2 \\
\text { kali panen }\end{array}$ & 10,21 & 915.37 & 9,76 & $9.801,20$ \\
\hline \multirow[t]{2}{*}{4} & Unaaha & $\begin{array}{c}\text { Lahan panen sesui } 2 \\
\text { kali panen }\end{array}$ & 2,68 & 211.76 & 12,66 & $1.984,27$ \\
\hline & & & & & 36,08 & 68.340,59 \\
\hline
\end{tabular}

Sumber: Data BPS Kabupaten Konawe 2018. 


\subsection{Estimasi Kebutuhan Beras}

Analisis ini di gunakan untuk mengetahui kebutuhan konsumsi beras setiap Kecamatan yaitu Kecamatan Pondidaha, Wonggeduku, Wawotobi, dan Unaaha pada tahun 2018. Seiring dengan pertambahan penduduk jumlah kebutuhan beras yang dibutuhkan pun turut mengalami peningkatan. Estimasi kebutuhan beras pada kecamatan unaaha, kecamatan wawotobi, kecamatan wonggeduku, dan kecamatan pondidaha dapat dilihat pada tabel 3

Tabel 3. Estimasi Kebutuhan Beras 2018

\begin{tabular}{ccccccc}
\hline No. & Kecamatan & $\begin{array}{c}\text { Jumlah } \\
\text { Penduduk } \\
\text { (jiwa) }\end{array}$ & $\begin{array}{c}\text { Produksi } \\
\text { Beras } \\
\text { (ton) }\end{array}$ & $\begin{array}{c}\text { Konsumsi } \\
\text { Beras } \\
\text { (ton/tahun) }\end{array}$ & $\begin{array}{c}\text { Kebutuhan } \\
\text { Beras (Ton) }\end{array}$ & Keterangan \\
\hline $\mathbf{1}$ & Unaaha & 26.027 & $1.984,27$ & 0,07 & $1.821,89$ & Memenuhi \\
\hline $\mathbf{2}$ & Wawotobi & 23.140 & $9.801,20$ & 0,07 & $1.619,8$ & Memenuhi \\
\hline $\mathbf{3}$ & Wonggeduku & 13.602 & $48.416,13$ & 0,07 & 952,14 & Memenuhi \\
\hline $\mathbf{4}$ & Pondidaha & 11.970 & $8.138,99$ & 0,07 & 837,9 & Memenuhi \\
\hline & & & & $5.231,73$ & \\
\hline
\end{tabular}

Sumber: Hasil Pengolahan Data

\section{KESIMPULAN}

Hasil analisis hasil luas lahan sawah pada tahun 2009 sebesar 4.291,6 Ha, kemudian pada tahun 2018 meningkat menjadi 7.162,67 Ha. pertamabahan luas lahan sawah dari tahun 2018-2009 sebesar 2.871,07 Ha.

Berdasarkan hasil analisis estimasi produksi tanaman padi dilakukan berdasarkan kelas produktivitas yang ditentukan jumlah panen per tahun. Berdasarkan analisis estimasi produksi tanaman padi pada empat Kecamatan di Kabupaten Konawe dalam areal Pengairan Bendungan Wawotobi yaitu Kecamatan Pondidaha di dapatkan hasil estimasi sebesar 8.138,99 ton dan kebutuhan beras 837,9 ton/tahun dengan jumlah penduduk 11.970 jiwa, Kecamatan Wonggeduku sebesar 48.416,13 ton dan kebutuhan beras 952,14 ton/tahun dengan jumlah penduduk 13.602 jiwa, Kecamatan Wawotobi sebesar 9.801,20 ton dan kebutuhan beras $1.619,8$ ton/tahun dengan jumlah penduduk 23.140 jiwa dan Unaaha sebesar 1.984,27 ton dan kebutuhan beras $1.821,89$ ton/tahun dengan jumlah penduduk 26.027 jiwa. Jadi dari empat Kecamatan tersebut kebutuhan beras tiap tahun memenuhi kebutuhan konsusmsi beras. Selain itu berdasarkan hasil kebutuhan beras jika bertambahnya jumlah penduduk maka kebutuhan beras akan meningkat, dan pada empat 70 --- April kecamatan tersebut mempengaruhi dalam pemenuhan kebutuhan dan ketahanan pangan dan memenuhi pendapatan penduduk Kabupaten Konawe.

\section{DAFTAR PUSTAKA}

Ashidqi, I. S., and Taryono, I. 2017. Analisis Estimasi Produksi Lahan Pertanian Padi di Kabupaten Brebes. [Skripsi] Surakarta: Program Studi Geografi, Fakultas Geografi, Universitas Muhamadiyah.

Febriyanto, Achmad, M., and Prawitosari, T. 2012. Identifikasi Perubahan Lahan Pertanian Di Kecamatan Mandai Kabupaten Maros Menggunakan Citra Landsat 5 TM Tahun 2002 , 2006 dan 2010. Makalah Yang Disajikan Pada Seminar Hasil Penelitian Program Studi Keteknikan Pertanian Program, Unhas 16 Oktober. Makassar.

Irawan, B. 2016. Konversi Lahan Sawah: Potensi Dampak, Pola Pemanfaatannya, dan Faktor Determinan, Bogor: Forum Penelitian Agro Ekonomi.

Sugiarto, 2013. LANDSAT 8: Spesifikasi, Keunggulan dan Peluang Pemanfaatan Bidang Kehutanan, 
http://tnrawku.wordpress.com/2013/ 06/12/ landsat - 8 - spesifikasi keungulan - dan - peluang emanfaatan - bidang kehutanan/ diakses November 2018.

Syaf, Hasbullah., Tufaila, M., Yunus, L., Baco, L., Karim, J., and Rauf, M. A. 2017. Analisis Kebutuhan Luas Lahan Pertanian Pangan Sebagai Dasar Perencanaan Dan Pengembangan Lahan Pertanian berkelanjutan di Kabupaten Konawe Selatan. [Skripsi] Kendari : Universitas Halu Oleo.
Syaifuddin, Suprapto, M., and Syafi'i , 2013. Evaluasi Kinerja Daerah Irigasi, Jurnal Teknik Sipil Magister Teknik Sipil Universitas Sebelas Maret, Vol.I No.1, p. 1-10.

Utami, F. P., Prasetyo, Y., and Sukmono, A. 2016. Analisis Spasial Perubahan Luasan Mangrove Akibat Pengaruh Limpasan Sedimentasi Tersuspensi Dengan Metode Penginderaan Jauh, Jurnal Geodesi Undip, Vol. 5 No 1, p. 305-315. 
JAGAT (Jurnal Geografi Aplikasi dan Teknologi)

ISSN : 2549-9181| e-ISSN : 2684-6705 | Vol.5 | No.1 | 2021

72 --- April 